\title{
Social impact analysis of cultural tourism in rural areas of Tlaxcala, Mexico
}

\section{Análisis del impacto social del turismo cultural en espacios rurales de Tlaxcala, México}

Luceli Méndez Serrano ${ }^{1}$, José Pedro Juárez-Sánchez ${ }^{2 *}$, Benito Ramírez-Valverde ${ }^{2}$, Laura Caso Barrera ${ }^{2}$

Originales: Recepción: 30/10/2019 - Aceptación: 11/11/2020

\section{Abstract}

Alternative tourism, specifically cultural tourism, has gained worldwide importance. This is reflected in the growing number of people preferring this type of leisure activity. However, and even though archaeological and religious contexts represent hubs of attraction for pilgrims and tourists, their development seems to generate social issues. The objective of this research is to analyse the social impact of cultural tourism, from the perspective of tradesmen living in the rural municipality of Tlaxcala, Mexico. Information was collected by surveys. Sample size was calculated using the non-probabilistic method (snowball), and 54 tradesmen owning establishments near tourist attractions, were interviewed. Results evidenced that tradesmen do perceive social problems including traffic congestion, increasing living costs, pollution, street vendors, and augmented competition between businesses. However, they appreciate the benefits of providing tourists with low-cost catering services, considering tourism to be positive or very positive. The conclusion is that economic benefits outweigh the social impacts generated by tourism.

\section{Keywords}

cultural tourism • rural spaces • developing • impacts

1 Master's Student PROEDAR. Colegio de Postgraduados Campus Puebla. Km. 125.5. Carretera Federal México-Puebla (Boulevard Forjadores de Puebla). C. P. 72760. lucelimendezs@gmail.com.

2 Qualified Research Professors at the Campus of the Postgraduate College in Puebla. * pjuarez@colpos.mx 


\section{RESUMEN}

El turismo alternativo y específicamente, el cultural ha adquirido importancia a escala global y se refleja en el crecimiento del número de personas que prefieren este tipo de esparcimiento. Así los espacios arqueológicos y religiosos, son polos de atracción para peregrinos y turistas, pero su desarrollo está generando problemas sociales. El objetivo de la investigación fue analizar el impacto social del turismo cultural, desde la percepción de los comerciantes en un municipio rural de Tlaxcala, México. Se recabó la información mediante la técnica del cuestionario, se calculó la muestra utilizando el método no probabilístico (bola de nieve), se entrevistaron a 54 comerciantes que poseen establecimientos cerca de los atractivos turísticos. Se encontró que los comerciantes obtienen escasas utilidades, al brindar servicios de restauración de bajo costo a los turistas. También perciben que se están incrementando los problemas sociales incluido el tráfico, incremento del costo de la calidad de vida, contaminación, ambulantaje, y una mayor competencia entre negocios. A pesar de ello, consideraron que la actividad turística es buena o muy buena y contribuye al desarrollo local. Se concluye que aún son más los beneficios económicos que los impactos sociales generados por el turismo y por lo tanto se acepta su desarrollo.

\section{Palabras clave}

turismo cultural $\bullet$ espacios rurales $\bullet$ desarrollo $\bullet$ impactos

\section{INTRODUCTION}

Tourism has become one main promoter of economic growth in many countries, especially in those undeveloped. In Mexico, its advancement is an economic priority. In 2018, this country resulted the seventh most visited destination in the world, with the arrival of 42 million international tourists (37). In recent decades, the tourism industry has faced the challenge of satisfying the individual needs of tourists, rather than addressing the mass market (33). In this context, cultural tourism gains importance, as several cultural resources, converted into touristic attractions, constitute a contributing strategy for economic development.

Cultural tourism constitutes a social phenomenon that rescues the historical aspect of cultural heritage in order to contribute to territorial development (18). The UNWTO (World Tourism Organization) defines this type of tourism as a "social phenomenon" consisting of cultural trips considering folklore, arts and crafts, festivals, sites, monuments, and pilgrimages (12). This organization reaffirmed that cultural tourism represents an important part of international tourism, comprising more than $39 \%$ of arriving tourists (34). In Mexico, it included more than $40 \%$ of cultural trips (14), representing 5.5\% of international travellers and $3 \%$ of national travellers (38).

Regarding this business, Mexico is especially competitive, given its artistic and historical value in terms of pre-Hispanic civilizations and colonial history, as well as its traditional cities and cultures (21). In this context, more than 1,200 museums and about 200 archeological sites are open to the public. Mexico has 121 destinations termed as Magical Centers by the Ministry of Tourism. According to the National Institute of Statistics and Geography (2017), in 2016, the state of Tlaxcala received a total of 368,229 national visitors and 20,944 foreigners. Of this total, the archeological zones of Cacaxtla $(144,589)$ and Xochitecatl $(119,446)$ attracted the greatest number of tourists $(87.5 \%, 20)$.

This intense influx of tourists may negatively or positively disturb the host culture (31). Touristic development causes different social effects, especially evident in developing countries (1). Social behaviour plays a central role in human interactions. Mendoza et al. (2011) state that tourism impact assessment is fundamental. In this context, social impacts generated by tourism, principally on host communities, have not been evaluated. Our hypothesis states that social problems are increasing, with great competition between handicraft vendors as a result of the greater influx of tourists in the communities of San Miguel del Milagro, San Miguel Xochitecatitla and San José Atoyatenco, located in the municipality of Nativitas, Tlaxcala. 


\section{BIBLIOGRAPHIC REVIEW}

\section{Social impact of tourism in rural areas}

Territorial heritage derives from highly proclaimed and socially recognized cultural and natural inherited resources, making them a valuable cultural product (28). Thus, both nature and culture are important, especially if they coexist (9). Its interpretation combines material and immaterial aspects, representing elements with social assigned value and meaning, such as inheritance or collective legacy. This is linked to geographical diversity, as the resources included in the List of World Heritage of the United Nations Educational, Scientific and Cultural Organization (UNESCO), are characterized as universal and exceptional (42). These, in addition to others not included in this organization's list but combining the necessary attributes.

In cultural tourism, the heritage-tourism binomial correlation, stands out. The society vs. nature relationship needs to be considered, while analysing the impacts of existing economic, social and cultural affairs. Tourism results from the economic and social changes occurring in the context of societies from which it emerges. Its development focuses on its natural and cultural resources (27). Thus, both positive and negative transformations take place in all contexts, including rural ones. This means that touristic development brings economic benefits in exchange for social and environmental impacts $(5,13)$. Therefore, to analyse the perception of the local population regarding the effects of tourism, and its impact on socio-economic environments, turns important (35).

Santos (2004) commented that concerning the social aspect, tourism promotes changes in well-being, assimilation and transformation of customs. Likewise, tourism can cause negative changes like increasing insecurity, drug addiction and alcoholism. Social tension is also caused by land purchase for touristic infrastructure or when areas close to cultural heritage, are occupied. Timothy and Gyan (2009), mention that when different social groups claim the same space, event or object as their own, conflict and social discord can arise. These issues represent negative social manifestations of tourism.

Pedersen (2005) argues that, even though rapid touristic growth leads to environmental difficulties, increased property and commodity prices, traffic congestion, decreased life quality, higher taxes and competition in terms of the distribution of benefits, residents still maintain a positive attitude towards tourism, approving its development. This means that, despite the impacts of touristic development on communities, their inhabitants consider it an ensuring survival strategy. Even though tourism by itself, is not sufficient to eliminate poverty, it contributes to its reduction. Many job positions are generated from this activity, benefiting local inhabitants (24).

In this sense, the social exchange theory studies how residents perceive these impacts and how their perceptions may affect their approval or rejection (39). This theory analyses the trending attitudes of residents toward this activity (7). It also helps explain social changes arising from touristic activities, and attempts to provide a general theory of interaction, whose object of study is the group phenomena complying with norms, cohesion, group status and power, among others. Social human behaviour manifests between two or more people interacting spontaneously, expecting to achieve their aspirations (26). In this exchange, power as a positive factor plays an important role in the impacts of tourism involving submission or prohibition. Vargas-Núñez et al. (2011) affirmed that power is the capacity to decide on one's own life, but also the competence to decide on other lives. It can be considered a social interaction attribute, providing the link by which rules are established. It also provides procedures leading to unanimous and common agreement. Thus, status and power are unilateral relationships, resulting from this exchange. Additionally, the social exchange theory also contributes to understanding inhabitant's perception, assuming they select their transactions once having assessed their costs and benefits. If the benefits economic or social - are greater than the costs involved, residents will support touristic development, being hospitable and tolerant towards tourism and its negative issues $(8,32)$.

Ap (1992) stated that when resource exchange turns high for the host, residents consider the impacts of tourism to be positive. But when the exchange is low, whether in a balanced or unbalanced relationship, impacts are perceived as negative. The rural economic framework should also be considered, given that if people are immersed in an agricultural 
and economic crisis, they will accept these types of activities, despite the low perceived income (15). Over time, social interaction causes change. Morales (2002) mentioned that at first, people adopt a positive view, enabling exchanges in which benefits are obtained. However, over time, differences develop onto unilateral dependence on power. Here, the social exchange relationship goes unnoticed, meaning that the negative aspects of tourism start being noticed. Residents perceive price increases, in addition to negative social impacts such as pollution, drug addiction and road congestion. Harrill (2004) states that people enjoying the greatest economic benefit, will be those who support touristic activities, as they place economic compensation before environmental or cultural costs.

In rural areas, changes in economic activities among inhabitants, bring negative transformations. In many communities, farmers integrated into the economy of tourism, leave agriculture. Others are forced to fabricate and sell low-value souvenirs, or to provide low-cost catering services to tourists, obtaining little profit, while economically generous margins are controlled by large companies (6). This implies that income generated from tourism does not remain in the hands of local people. Instead, it is mostly appropriated by international or regional tour operators.

Substituting agricultural activities for non-agricultural jobs, specifically tourism, has impacted on the social structure of rural areas. Although touristic income is low, some farmers complement their commercial income with this activity $(17,31)$. Therefore, to identify the social impacts of tourism on the sustainable development of local communities is important. Sites that offer cultural heritage should be analysed in reference to the magnitude of social impact, minimizing conflict between tourists and residents, while optimizing social development (23). Likewise, inhabitants' attitude towards touristic development, needs to be understood, reducing resentfulness, and promoting the touristic destination.

\section{METHODOLOGY AND CHARACTERISTICS OF THE STUDY AREA}

This research aimed to determine how salesmen perceive the social impacts of cultural tourism in the communities of San Miguel del Milagro, San Miguel Xochitecatitla and San José Atoyatenco, located in the municipality of Nativitas, Tlaxcala. The municipality is located south of the state of Tlaxcala, at 2,202 meters above sea level and between $19^{\circ} 14^{\prime}$ North latitude and $98^{\circ} 18^{\prime}$ West longitude (19). The study communities include the San Miguel Arcángel Sanctuary (religious tourism) and the Archeological Zones of Cacaxtla and Xochitecatl (archeological tourism), comprising the most visited attractions in the State (figure 1, page 324).

In 2015, the municipality of Nativitas had a population of 25,053 people, of who (figure 1, page 324), pam, 51.9\% were women. Eighty-eight percent of the people, aged 15 or older, was able to read and write. The Economically Active Population reached 9,346 people, of whom, $31.6 \%$ worked in the service sector, $26.4 \%$ in the primary sector, $25.8 \%$ in the secondary sector and $14.7 \%$ in commerce (19). Primary economic activities include agriculture, livestock and forestry, being maize, amaranth and vegetables, their main crops.

A bibliographic review of tourism, cultural tourism and the theory of social exchange was undertaken, explaining the objective of this study. A structured questionnaire including 70 variables related to social and economic aspects of tourism was complemented with direct observation techniques, implying that the researcher visited the study place (22). The sample was defined after the non-probabilistic method by applying the snowball technique, given that no register of the existing businesses in the studied communities, was found. 24 of the 54 people interviewed, pertained to the context of religious tourism, while 30 worked at archaeological sites. The owners or representatives of various businesses - shops or stalls, food services, lodging/hotels, and handicraft shops among others- were interviewed. Data were analysed by parametric and non-parametric statistics. 


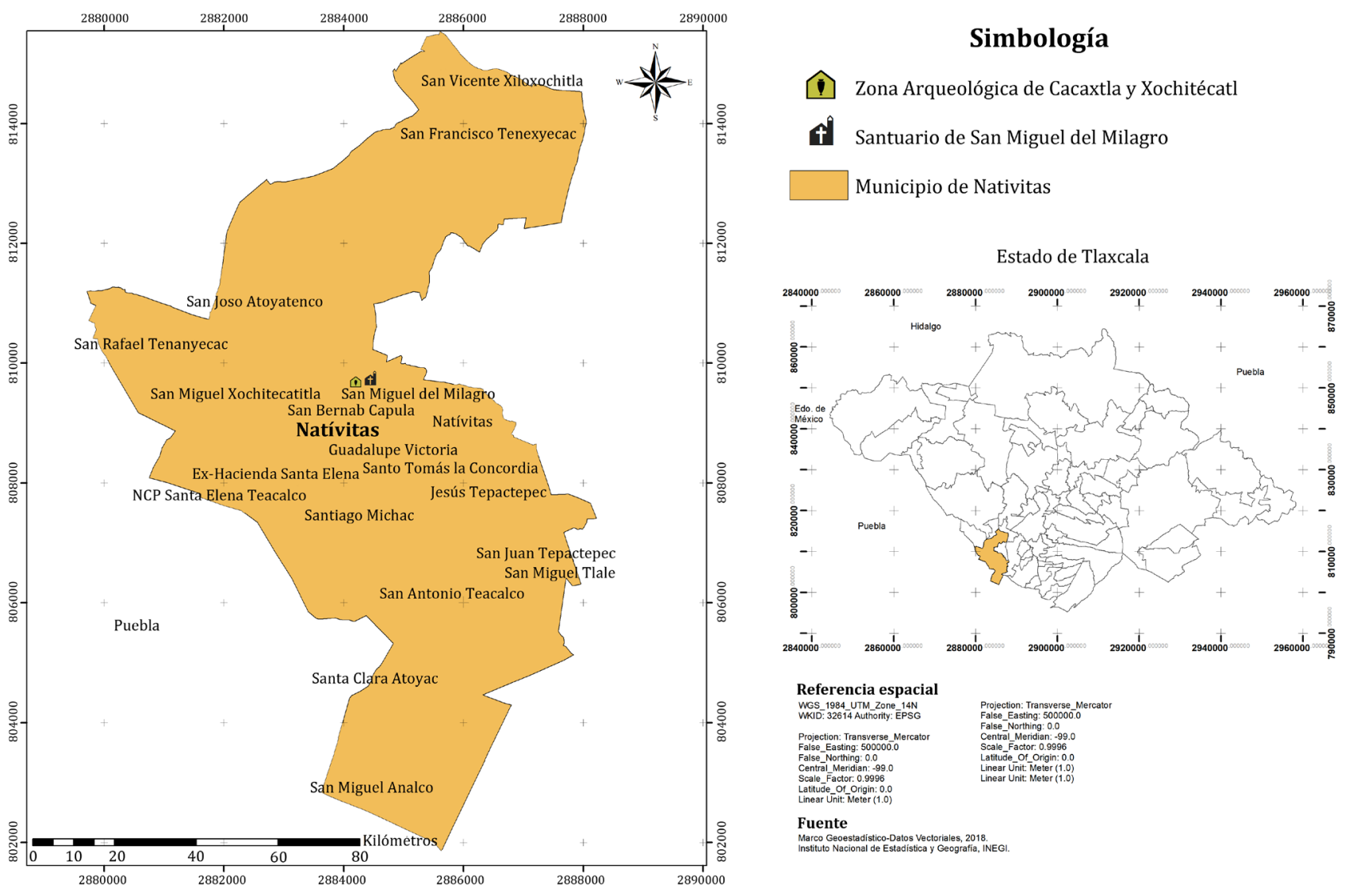

Figure 1. Spatial location of the municipality of Nativitas and tourist places.

Figura 1. Ubicación espacial del municipio de Nativitas y sitios turísticos.

\section{RESULTS AND DISCUSSION}

\section{Analysis of the social impact of cultural tourism.}

During the 70s and 80s, the study communities were mainly agricultural. The original inhabitants were Xicalanca Olmecs from the Chontalpa of Tabasco (10), people with significant cultural importance. However, today, agriculture has become a less important activity. Almost $43 \%$ of the interviewees stated they were tradesmen - they run a shop, or sell amaranth, clothes, hats and pottery sculptures, among other items. Thirty-seven percent provides some type of tourist service, food sales, lodging, parking and toilets, while the remaining percentage stated to be craftsmen. This means that Non-Agricultural Rural Employment (NARE) is becoming important, transforming the work activity at the studied locations. In this regard, Köbrich and Dirven (16) commented that NARE provides work for approximately $35 \%$ of the rural workforce in Latin American countries.

In this study, $64.8 \%$ of the interviewees stated to have other activities in addition to working as tradesmen or in tourism services: $48.6 \%$ work in agriculture, $22.9 \%$ have another occupation and the remaining percentage work for companies or the government. Those involved in religious tourism, chose agriculture $(68.8 \%)$ over those in archaeological tourism (31.6\%). This means that for some interviewees, tourism is a full-time job and not a complement to agriculture, contributing to the fact that, in the study area, agriculture is losing importance. People started up their businesses relying on family inheritance, both in religious (20.8\%) and in archaeological tourism (36.7\%). In this regard, Carton de Grammont (2015), recognized that this main non-agricultural activity takes place under precarious conditions and low income, where the most deprived households manage to find better paid self-employment. This is the case for most businesses in the study area. 
Consequently, cultural tourism may contribute depending on the type of activities and the characteristics of the local economy (30). This result is a consequence of touristic areas evolving over time, given that, as facilities and place awareness grow, the number of visitors also increases (25), partly explaining why tourism had varying impact on business establishment in the study areas.

Given the significant economic benefits, an increasing number of establishments resulted in greater competition. According to $79.2 \%$ of the respondents, competition between establishments offering similar assets increased in the religious context, as clearly observed in 2012. A similar phenomenon was observed in archaeological areas, where $83.3 \%$ of respondents said that competition between businesses offering similar services increased, while $87.5 \%$ involved provision of touristic services, such as food selling. Among those engaged in commerce, $32 \%$ stated that competition had increased. These data evidence greater interest in commercial activities in areas with religious tourism, while in the archaeological context, interest seems to be focused on providing services. This can partly be explained by the fact that tourists' perception of valuable monuments is inadequate, as scientific-cultural activities are not properly appreciated (40).

Interviewees indicated that tourism has been positive $(64.8 \%)$ and moderately positive (31.5\%). In terms of positive aspects; transportation (38.9\%), public services (16.7\%) and lighting (13\%) improvements, stood out. Concerning religious tourism, interviewees indicated that it has had a positive impact in terms of transportation improvement (58.4\%) and implementation of public infrastructure (12.5\%). Public routes were constructed, and public lighting was increased. In this sense, Zhuang et al. (2019), commented that tourism can improve local life standards, improving infrastructure, medical and educational care, employment opportunities and income levels.

Regarding conflicts within the population, $22.2 \%$ answered that tourism generates problems, to a greater extent as a result of religious tourism (45.8\%), compared to archaeological tourism (3.3\%). In this context, Almeida et al. (2015) mentioned that interactions between local residents and tourists may generate anguish and pressure. At different stages in their lives, residents may feel that their social reality is threatened. In order to understand conflict perception among the population towards tourism, several variables were analysed according to the logistic regression model. Using a variable selection procedure, variables were included and discarded until the appropriate model was obtained. Finally, the presence of street vendors near touristic places and the usage of parking spaces resulted to be significantly associated with conflict (table 1).

Table 1. Estimators of the logistic regression model, using the forward stepwise selection method (Wald).

Tabla 1. Estimadores del modelo de regresión logística con el método de selección por pasos hacia adelante (Wald).

Source: survey data,

2017.

Fuente: datos de la encuesta, 2017.

\begin{tabular}{|l|c|c|c|c|c|}
\hline \multicolumn{1}{|c|}{ Variables } & $\boldsymbol{B}$ & E.T. & Wald & $\boldsymbol{P}$ & $\operatorname{Exp(B)}$ \\
\hline Presence of tradesmen & 1.140 & .433 & 6.930 & .008 & 3.125 \\
\hline Parking spaces & -2.214 & .835 & 7.032 & .008 & 0.109 \\
\hline Constant & 6.425 & 3.071 & 4.378 & .036 & 616.984 \\
\hline
\end{tabular}

Problem perception after touristic arrival could be related to territorial planning, given that the presence of street vendors had not been regulated and the creation of parking lots meeting the service demand, had not been encouraged. In order to analyse whether the inhabitants of the study communities perceived that tourism caused vehicle traffic congestion in their respective communities, a correspondence analysis was carried out. This technique studies the dependency relationships of a set of categorical variables from the data, in a contingency table. A statistically significant relationship between the variables, study communities and increased traffic congestion $\left(\chi^{2}=41,795 ; p<0.001\right)$ was found, suggesting a relationship between traffic and communities. Two groups are defined: 1) In the community of San Miguel del Milagro, religious tourism caused massive traffic increases, 2) In the San Miguel communities of Xochitecatitla and San José Atoyatenco, little or very little traffic resulted of archaeological tourism. Tourist arrivals to archaeological areas are less than in San Miguel del Milagro (figure 2, page 326). 
Source: Own elaboration based on survey data, 2017.

Fuente: Elaboración propia con base en datos de encuestas, 2017.

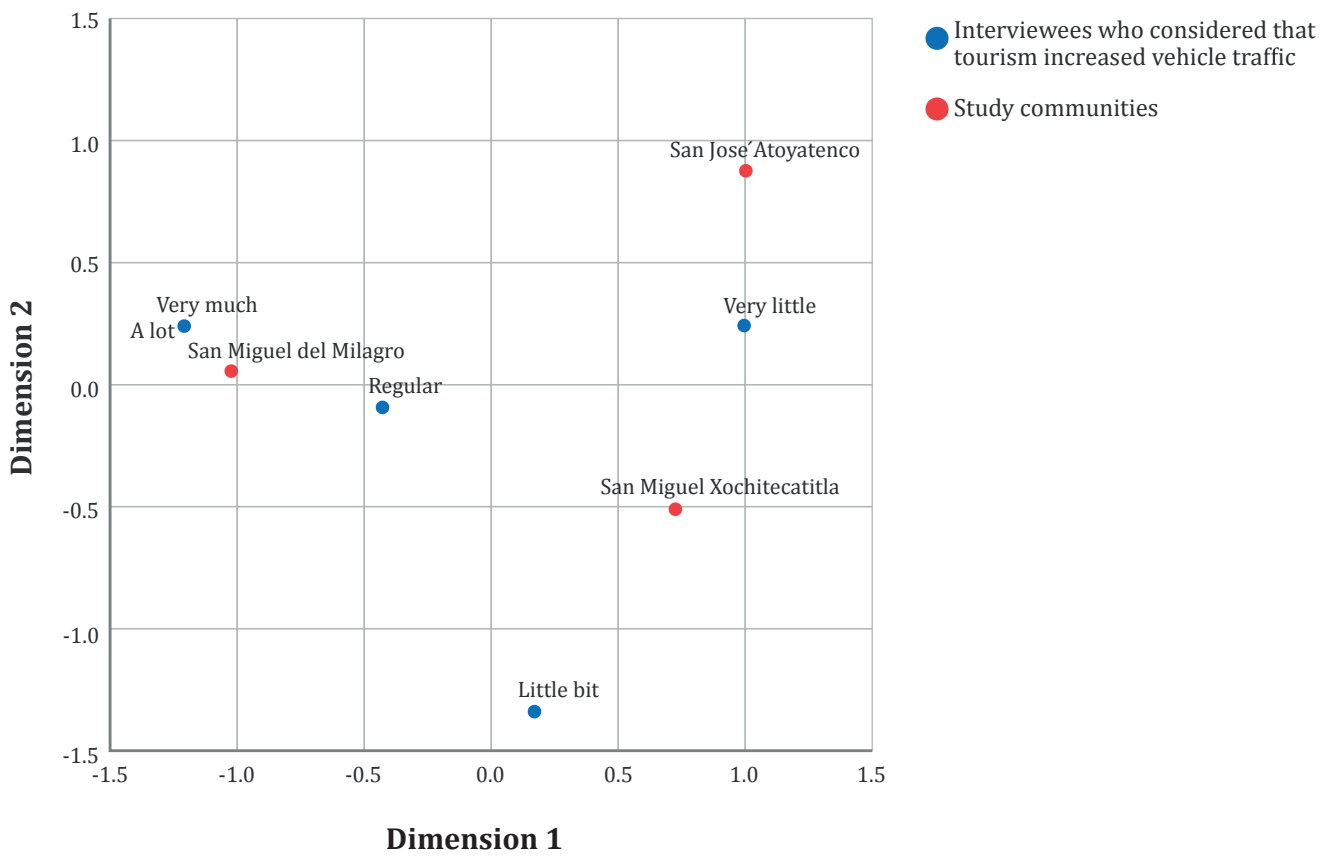

Figure 2. Correspondence analysis of the relationship between study communities and traffic impact.

Figura 2. Análisis de correspondencia entre las comunidades de estudio y el impacto del tráfico vehicular.

When specifically asking about discontent, $16.7 \%$ of respondents in the religious tourism area said that traffic had increased greatly, while $45.8 \%$ thought it had increased, much. This adversity is aggravated during September, when the San Miguel del Milagro festival begins, and an increased number of pilgrims visit the sanctuary. This issue is partly a consequence of poor planning. In archaeological areas, traffic problems are still not present.

Interviewees (58.3\%), from the religious touristic area, complained about a great reduction in the number of available parking lots. However, in archaeological touristic areas, $73.3 \%$ of respondents considered almost no increase in traffic due to tourism. In this sense, $76.7 \%$ said that tourism didn't practically reduce the number of parking spaces, $50 \%$ said that neither is traffic excessive nor parking insufficient, and only $36.7 \%$ complained about insufficient space.

Among other negative aspects of tourism, interviewees mentioned pollution (48.1\%) and cultural change (33.3\%). In religious touristic areas, $37.5 \%$ complained about contamination, $37.5 \%$ complained about their community culture being impacted as a consequence of cultural exchange, and $25 \%$ observed road congestion negatively impacting society. In the archaeological touristic area, people mainly mentioned pollution (56.7\%), and to a lesser extent, cultural impact and water scarcity. These types of social impacts influence life standards at the tourist destination (8).

Tourism has also influenced the increasing cost of living (24.1\%), especially for religious touristic areas (41.7\%) and to a lesser extent in archaeological areas (10\%). In religious touristic areas, house rental (50\%), transport (40\%) and food (10\%) have increased. Archaeological tourism has contributed to rising costs of living, mainly food $(66.7 \%)$ and housing (33.3\%). This increased cost of living is due to new businesses established by extra-community people. In this sense, Pedersen (2005), mentioned research on local concerns in relation to the impact of tourism development. Among many problems that affect the religious touristic area, property value, traffic congestion, life standards, income and price increase, were mostly mentioned. 
Conflicts concerning tourism development and the appropriation of premises to establish a business (58.3\%), as well as issues concerning lack of communication between the authorities and their inhabitants (33.3\%), have arisen. This has led to vertical governmental decisions. In archaeological areas, people stated that this situation is creating social tension. Conflicts in religious touristic areas, concerning the occupation of premises, involved those who provide touristic services (75\%) and tradesmen (57.1\%).

Another complaint refers to the presence of street vendors and their business facilities, that contribute to the detriment of the area surrounding the tourist centres. Those interviewed about religious (54.2\%) and archaeological (10\%) tourism, stated that businesses established near the Sanctuary and the archaeological zones, needed to be re-located in specific areas. They also stated that both religious (37.5\%) and archaeological $(76.7 \%)$ tourism, require better facilities. As reflected by percentages, these touristic areas present different problems. In one, quality of facilities is essential, while in the other, business organization is of primary importance. However, the truth is that even though tourism represents a controversial social phenomenon, this activity promotes job positions and increasing income for the inhabitants (11).

Finally, with respect to security, according to respondents, the studied communities are safe or very safe (85.2\%) places to visit. Despite this, $50 \%$ of respondents added that, in recent years, a regular increase in assaults has been noted while $37.5 \%$ mentioned a few acts of aggression. Interviewees who stated that the communities are moderately safe, referred to the increase in assaults during the last two years. This phenomenon is not linked to the arrival of tourists, but to the existence of gangs from these areas and nearby communities, and the arrival of people from other cities, settling in these communities. It can be concluded that the interviewees consider that, despite social problems (traffic, increased life standards cost, pollution and street vendors), (7.4\%) tourism is very good and (66.6\%) good.

\section{CONCLUSIONS}

The study communities consist of small rural centres with less than 2,500 inhabitants receiving an important influx of tourists. Almost 130 thousand to 200 thousand tourists arrive annually, in each tourist area. Consequently, tourism is contributing to the transformation of their social environment, meaning that with the arrival of tourists, increasingly rural non-agricultural employment is becoming more important. Almost half of respondents work as tradesmen or in tourism services, indicating that agriculture is losing importance. This type of transformation was more evident in the archaeological zones, where tourism is a full-time employment alternative. Unfortunately, these new activities are carried out under precarious conditions and for fundamentally low salaries.

Tourism is creating conflict in communities, especially in the religious touristic area, where a greater influx of tourists causes a differential increase in the number of businesses, resulting in greater competition. Additionally, tourism also brings more traffic, resulting in less public parking for local cars. Likewise, stalls and consequently more rubbish, are generated. Finally, an increased cost of living completes the disadvantages of touristic development. Perception of Tourism-related problems seems to be associated with poor regional urban planning, as the presence of street vendors and the creation of parking lots have not been regulated.

While promoting tourism is necessary, to ensure inhabitants wellbeing, is also important. In general, tourism-related problems are more pronounced in religious areas than in archaeological ones. If touristic activities are not properly planned, social impacts will increase, causing life quality deterioration with the consequent rejection of this type of economic activity. Thus, to implement strategies that help reduce the negative social impacts of tourism, becomes necessary. Future research should be carried out by incorporating the inhabitants, especially the peasants, and their perception of the social impacts of tourism in their community. 


\section{REFERENCES}

1. Alipour, S.; Kaboudi, M. 2012. Community perception of tourism impacts and their participation in tourism planning: A case study of Ramsar, Iran. Procedia - Social and Behavioral Sciences. 36: 333-341.

2. Almeida, F.; Balbuena, A.; Cortés, R. 2015. Resident's attitudes towards the impacts of tourism. Tourism Management Perspectives. 13: 33-40.

3. Ap, J. 1992. Residents perceptions on tourism impacts. Annals of Tourism Research. 19(4): 665-90.

4. Carton de Grammont, H. 2015. El empleo rural no agrícola en México: el caso de la industria de la confección. En: Asalariados rurales en América Latina. Riella, A. y Mascheroni, P. (Coord.). Edit. Consejo Latinoamericano de Ciencias Sociales. 313-339.

5. Castaño-Quintero, P. A.; Gil-Cerezo, M. V.; Galán Soldevilla, C.; Domínguez-Vilches, E. 2020. Analysis of the implementation of the "Man and the Biosphere" programme in the biosphere reserves of Andalusia. Revista de la Facultad de Ciencias Agrarias. Universidad Nacional de Cuyo. Mendoza. Argentina. 52(1): 128-147.

6. Díaz-Andreu, M. 2014. Turismo y arqueología. Una mirada histórica a una relación silenciada. Anales de Antropología. 48(2): 9-40.

7. Dutt, C. S.; Harvey, W.; Shaw, G. 2018. The missing voices in the perceptions of tourism: The neglect of expatriates. Tourism Management Perspectives. 26: 193-202.

8. Ellis, S. 2007. Resident community perceptions of the socio-cultural impacts of tourism and host guest relations in a least developed country: An exploratory study of Phnom Penh, Cambodia. https://ro.ecu.edu.au/theses_hons/1316

9. Fernández, F.; Estrada, I. 2014. Esencialización y espectacularización de lo maya. Turismo voluntario y étnico en una comunidad yucateca. Scielo. Península. 9(1): 9-31.

10. Foncerrada, M. 1987. Un fragmento de pintura mural en Cacaxtla, Palenque y El Popol Vuh. Anales del Instituto de Investigaciones Estéticas. 15(5): 29-33.

11. Gámez, A.; Ivanova, A.; Wilson, T. 2011. Género y comercio informal en destinos turísticos. El caso de las vendedoras de playa en los Cabos, Baja California Sur, México. Turydes. 4(9): 6.

12. Hargrove, C. 2014. Cultural tourism: attracting visitors and their spending. National Cultural Districts Exchange. 27 p.

13. Harrill, R. 2004. Residents' attitudes toward tourism development: A Literature Review with Implications for Tourism Planning. Journal of Planning Literature. 18(1): 251-256.

14. Hiriart, C. 2011. Panorama mundial del patrimonio cultural. México: Facultad de Arquitectura de la Universidad Michoacana de San Nicolás de Hidalgo. ICOMOS. Cuadernos de Patrimonio Cultural y Turismo. México. 16-18.

15. Juárez, J. P.; Ramírez, B.; Mota, J. A. 2017. ¿Las peregrinaciones rurales impulsan el desarrollo local? Análisis en San Miguel del Milagro, Tlaxcala, México. El Periplo Sustentable. 33: 428-451.

16. Köbrich, C.; Dirven, M. 2007. Características del empleo rural no agrícola en América Latina con énfasis en los servicios. Unidad de Desarrollo Agrícola y División de Desarrollo Productivo y Empresarial. CEPAL. 174(1): 84.

17. Llambi, L.; Pérez, E. 2007. Nuevas ruralidades y viejos campesinismos. Agenda para una nueva sociología rural latinoamericana. Cuadernos de Desarrollo Rural. 4(59): 37-61.

18. López, T.; Lara, F.; Merinero, R. 2006. Las rutas turísticas como motor de desarrollo económico local. La ruta del Tempranillo. Estudios turísticos. 167: 131-145.

19. INEGI. 2017. Anuario estadístico y geográfico de Tlaxcala 2017. Instituto Nacional de Estadística y Geografía. México. 577 p.

20. Instituto Nacional de Antropología e Historia, INAH. 2017. Sistema de información cultural, Zonas arqueológicas.

21. Mantecón, A. 2010. El giro hacia el turismo cultural: participación y desarrollo sustentable. Cuadernos de Patrimonio Cultural y Desarrollo. (20): 161-184.

22. Mendoza, M. 1994. Técnicas de observación directa para estudiar interacciones sociales infantiles entre los Toba. RUNA. (21): 241-262.

23. Mendoza, M. M.; Monterrubio, J. C.; Fernández, M. J. 2011. Impactos sociales del turismo en el centro integralmente planeado (CIP) Bahías de Huatulco, México. GESTUR. (15): 47-73.

24. Millán, G.; Amador, L.; Arjona, J. M. 2016. El paisaje agavero y la planificación turística sostenible. Un requisito para su permanencia como sitio patrimonio de la humanidad. Scripta Nova. 20: 537.

25. Monterrubio, J. C. 2008. Residents perceptions of tourism: A critical theoretical and methodological review. Ciencia Ergo Sum. 15(1): 35-44.

26. Morales, J. F. 2002. La teoría del intercambio social desde la perspectiva de Blau. REIS. (4): 129-146.

27. Ogechi, E.; Oyinkansola, O. 2012. Social impact of tourism development on host communities of Osun Oshogbo Sacred Grove. Journal of Humanities and Social Science. 2(6): 30-35.

28. Ortega, J. 1998. El patrimonio territorial: el territorio como recurso cultural y económico. Ciudade. (4): 33-48.

29. Pedersen, A. 2005. Gestión del turismo en sitios del Patrimonio Mundial: Manual práctico para administradores de sitios del Patrimonio Mundial. Centro del Patrimonio Mundial de la UNESCO. España. 
30. Plzáková, L. 2015. Economic and social impacts of cultural tourism. $2^{\text {nd }}$ International Multidisciplinary Scientific Conference on Social Science and Arts, Book 2 Political Science. Law, Finance, Economics and Tourism. Bulgaria. 3 p.

31. Quintero Peralta, M. A.; Gallardo-Cobos, R. M.; Sánchez-Zamora, P. 2020. The need for extra-agrarian peasant strategies as a means of survival in marginal rural communities of Mexico. Revista de la Facultad de Ciencias Agrarias. Universidad Nacional de Cuyo. Mendoza. Argentina. 52(1): 246-260.

32. Ramón, J. 2012. Actitudes de los residentes hacia el turismo en destinos turísticos consolidados: el caso de Ibiza. Tesis doctoral. Universitat de les Illes Balears, Departament d'Economia de l'Empresa Programa de Doctorat d'Economia de l'Empresa. España.

33. Reisinger, Y. 2012. International turismo. Cultures and behavior. Routledge. 420 p.

34. Richards, G. 2018. Cultural tourism: A review of recent research and trends. Journal of Hospitality and Tourism Management. 36: 12-21.

35. Sancho, A.; García, G.; Rozo, E. 2007. Comparativa de indicadores de sostenibilidad para destinos desarrollados en desarrollo y con poblaciones vulnerables. Annals of Tourism research. 9(1): 150-177.

36. Santos, J. L. 2004. Los impactos económicos, socioculturales y medioambientales del turismo y sus vínculos con el turismo sostenible. Anales del Museo de América. (12): 263-274.

37. SECTUR, 2018. Análisis de mercados, perspectivas del turismo mundial. Revista Visión Global del Turismo a México. Secretaría de Turismo. 25 p.

38. SECTUR y CESTUR, 2002. Estudios estratégicos de viabilidad para el segmento de turismo cultural en México: Secretaria de Turismo de México y el Centro de Estudios Superiores en Turismo. México.

39. Šegota, T.; Mihalič, T.; Kuščer, K. 2017. The impact of residents' informedness and involvement on their perceptions of tourism impacts: The case of Bled. Journal of Destination Marketing and Management, 6(3): 196-206.

40. Stratan, A.; Rodica, P.; Gribincea, C. 2015. Identifying cultural tourism potentials in Republic of Moldova through cultural consumption among tourists. Procedia - Social and Behavioral Sciences. (188): 116-121.

41. Timothy, D.; Gyan, N. 2009. Culture heritage and tourism in the developing world: A regional Perspective. New York: Routledge.

42. Troitiño, M. Á.; Troitiño, L. 2018. Visión territorial del patrimonio y sostenibilidad del turismo. Boletín de la Asociación de Geógrafos Españoles. (78): 212-244.

43. Vargas-Núñez, B. I. 2011. Estilos de poder, apreciación de la relación y de sí misma: variables que median en la mujer, estar o no en una relación de violencia. Interamericana de Psicología. 45(1): 37-48.

44. Zhuang, X.; Yao, Y.; Justin, J. 2019. Sociocultural impacts of tourism on residents of world cultural heritage sites in China. Sustainability. 11(3): 2-19. 